\title{
A Personal View of EVA London: Past, Present, Future
}

\author{
Jonathan P. Bowen \\ School of Engineering \\ London South Bank University \\ United Kingdom \\ http://www.jpbowen.com \\ jonathan.bowen@Isbu.ac.uk
}

\begin{abstract}
I first encountered EVA London in 1995 through my establishment of the Virtual Library museums pages (VLmp), part of the World Wide Web Virtual Library. In 2003, I was invited back as a keynote speaker on the subject of website accessibility for cultural heritage resources. Since then I have been involved with every EVA London conference either as an author or since 2007 as a proceedings editor. This paper summarises the developments of the EVA London conference over the past 25 years from a personal viewpoint and celebrates the 30th anniversary of EVA London and the whole family of international EVA conferences. The development of the community around EVA (Electronic Visualisation and the Arts) is evaluated in the context of a Community of Practice. The paper also considers possible future directions for EVA.
\end{abstract}

EVA London. EVA International. Online museums. Digital culture. Community of Practice.

\section{BACKGROUND}

The first EVA London conference was held at Imperial College London in 1990, organised by the EVA progenitor Jim Hemsley and others (Hemsley 2013). It grew out of the European ESPRIT-funded collaborative VASARI project, investigating ultrahigh-quality imaging of paintings to aid conservation as well as supporting art history education. Partners were from academia, industry, and museums, in France, Germany, Italy, and the United Kingdom. The conference was initially called "Electronic Imaging \& The Visual Arts" and has evolved to its current title of "Electronic Visualisation and the Arts", always maintaining the "EVA" moniker.

During the mid to late 1990s, the EVA Conferences spread across Europe, including Berlin, Brussels, Florence, Madrid, and Paris (Hemsley 2013). There are still regular annual EVA conferences in Berlin and Florence, with Paris restarting in 2018. There have been further EVA conferences worldwide, some of which have been one-off events, and others of which have developed into conference series. EVA/Minerva Jerusalem has taken place regularly. EVA Moscow became the largest European EVA conference series for several years (around 700 participants) and was subsequently held in St Petersburg in 2017. The largest ever EVA conference was EVA Gifu, held in Japan during 1998, with over a thousand participants, and attended by Jim Hemsley's daughter, Christina Hemsley. More recently, EVA Australasia was held in Canberra in 2016, EVA Copenhagen in 2018, and EVA/Minerva Brazil in São Paulo in 2019. All EVA conferences have included international participants. Online links to current EVA conference websites have been maintained by the author on the EVA website (http://eva-conferences.com) during recent years.

\section{EVA LONDON IN THE 1990s}

My first attendance at an EVA London conference was in 1995 at the National Gallery. In 1994, I had established the Virtual Library museums pages (VLmp), a directory of museums with online web resources (Bowen 1995a; 1995b). This attracted the attention of some technology-oriented personnel in the museum world involved with early museum websites (Gaia et al. 2020) as they discovered the resource (Bowen 1995c), including Jim Hemsley, the organiser of the EVA London conference. He invited me to a panel session at the EVA'95 London conference on the WWW and museums/libraries (see Figures 1 and 4). This resulted in a paper for the conference proceedings, 
which subsequently appeared an associated journal special issue (Bowen 1995d).

The presence of Eric Rask of the Canadian Heritage Information Network (CHIN) in the panel at EVA'95 was influential in CHIN being the first national museum organisation to host a mirror site for VLmp and also take on maintenance of a section of VLmp, namely Canadian museums (Bowen 1997).

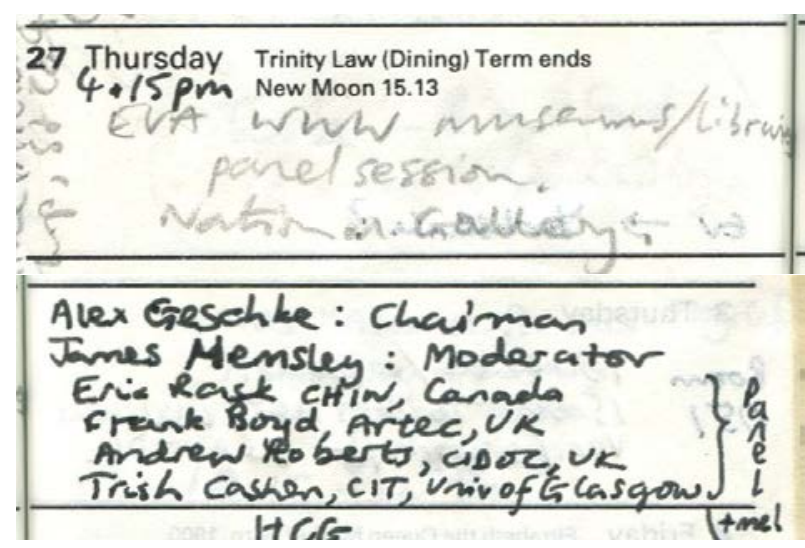

Figure 1: Diary entry for Thursday 27 May 1995. Panel session on the WWW and museums/libraries at EVA'95. (Courtesy of Jonathan Bowen.)

EVA'95 was held at the National Gallery in London, a legacy of the VASARI project, which included the National Gallery as a partner (see Figure 2).

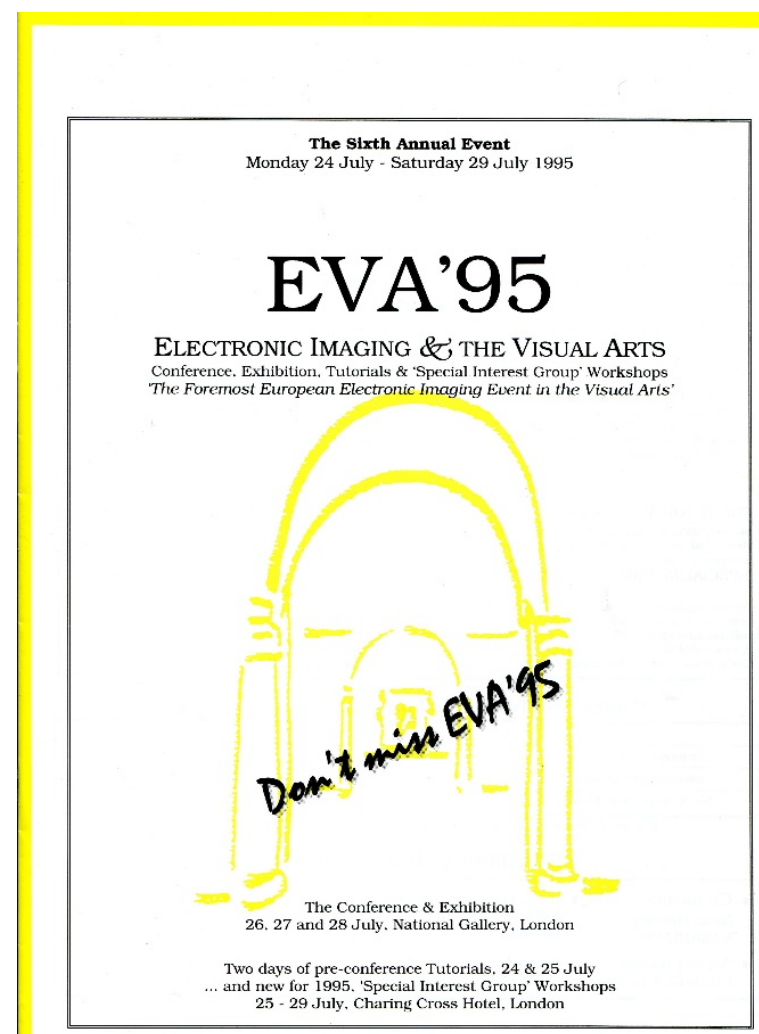

Figure 2: The front page of the EVA'95 leaflet.
EVA'95 in London was a turning point in terms of internationalising EVA, with international EVA conferences planned in Berlin, Paris, and Florence (see Figure 3).

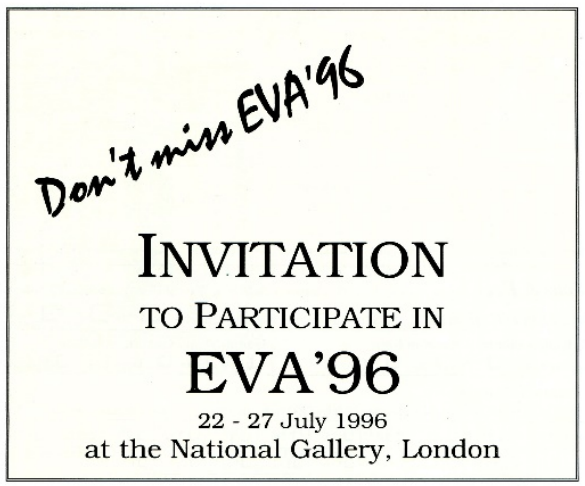

Abstracts are invited as soon as possible (November 15 at the latest) from those who are interested in giving:

\begin{tabular}{|c|c|}
\hline - Conference Paper • Tutorial - Workshop \\
• Demonstration at the EVA'96 Exhibition \\
\hline
\end{tabular}

$$
\text { KEY TOPICS INCLUDE: }
$$

- Case Studies - Small to Large
3-D Modclling \& Computer Graphics - Elcetronic Publishing $\quad *$ Intcractive Telcrisions

- Virtual Muscums \& Lbbrarics _. Market Forceastiny \& Copyright
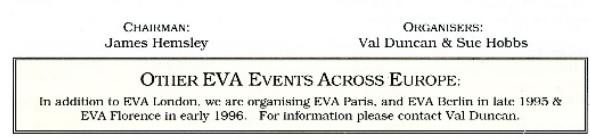

VASARI Limited, Clark House, 2 Kings Road, Fleet, GU13 9 AD

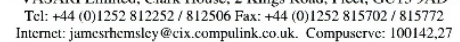

Figure 3: The back page of the EVA'95 leaflet. Note EVA Paris, EVA Berlin in 1995, EVA Florence in 1996.

In 1995, the World Wide Web was still a novel concept for EVA. There was no website URL included in the conference leaflet (Figure 2) and only one mention of the web in the panel session with which I was involved (see Figure 4).

Future Applications, Technologies, Standards \& Strategies

\begin{tabular}{|c|l|}
\hline $\begin{array}{l}\text { The International ART LINE Project and } \\
\text { AXIS National Artists Register for England }\end{array}$ & $\begin{array}{l}\text { YVONNE DEANE } \\
\text { AXIS. Leeds Metropoltan University, UK }\end{array}$ \\
\hline $\begin{array}{l}\text { Making Irish Art History Accessible } \\
\text { Remotely }\end{array}$ & $\begin{array}{l}\text { PHILIP MACEVANSONEYA } \\
\text { Trinity College, Dublin, Ireland }\end{array}$ \\
\hline $\begin{array}{l}\text { Users \& Usage of Multimedia in 1998 for } \\
\text { the New Museum of Scotland }\end{array}$ & $\begin{array}{l}\text { MIKE SPEARMAN } \\
\text { National Museums of Scotland, } \\
\text { Edinburgh. UK }\end{array}$ \\
\hline $\begin{array}{l}\text { The Future of Advanced Technologies, } \\
\text { IT \& Telecomms and the Role of the MDA }\end{array}$ & $\begin{array}{l}\text { WENDY SUDBURY } \\
\text { MDA. Cambridge, UK }\end{array}$ \\
\hline$\nabla \begin{array}{l}\text { Using the World Wide Web to Promote } \\
\text { Cultural Heritage including Museums and } \\
\text { Libraries }\end{array}$ & $\begin{array}{l}\text { A panel session } \\
\text { which will include: } \\
\text { ERIC RASK, CHIN, CANaDA } \\
\text { FRANK BOYD, ARTEC, UK } \\
\text { ANDREW ROBERTS. CIDOC, UK }\end{array}$ \\
\hline
\end{tabular}

Figure 4: The afternoon sessions on 27 May 1995 at EVA'95, including the panel session on the WWW and museums/libraries. 
In 1996, EVA was confidently advertising EVA conferences in Athens, Berlin, London, and Paris (see Figure 5).

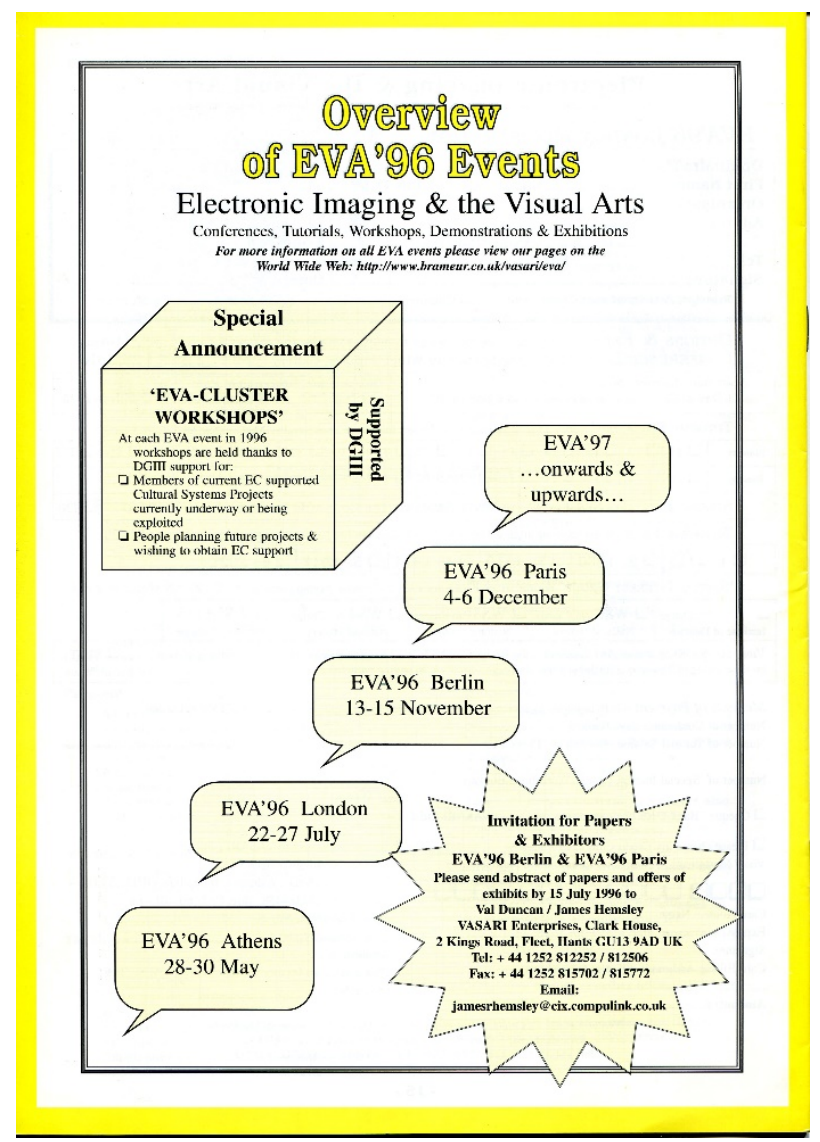

Figure 5: Overview of EVA'96 conferences in Athens, Berlin, London, and Paris.

I presented tutorials on the Internet and WWW aimed especially at museums in association with EVA'96 and EVA'97 in London (see Figure 6).

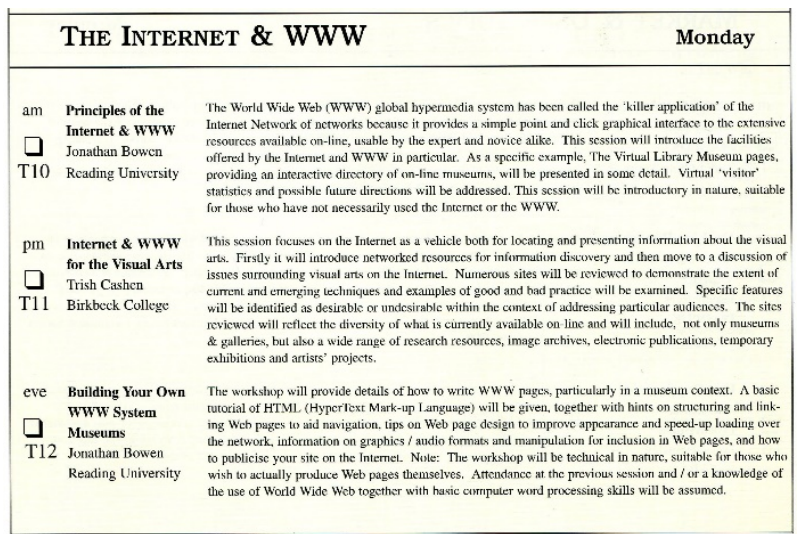

Figure 6: "The Internet \& WWW" tutorials at EVA'96 in London.

The EVA'97 leaflet was the first to include a web address for an EVA web page (see Figure 7). This displayed 1997 EVA conferences in Berlin, Brussels, London, Paris, and Thessaloniki.

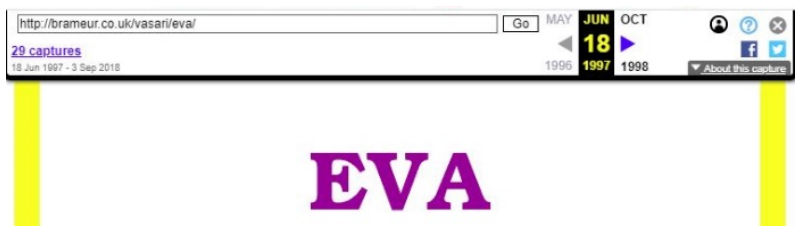

ELECTRONIC IMAGING \& THE VISUAL ARTS Conference, Exhibition, Tutorials \& 'Special Interest Group' Workshop The Foremost European Electronic Imaging Event in the Visual Arts

Dates now set at the following venues across Europe:

** Click on any of the bubbles below to obtain more information **
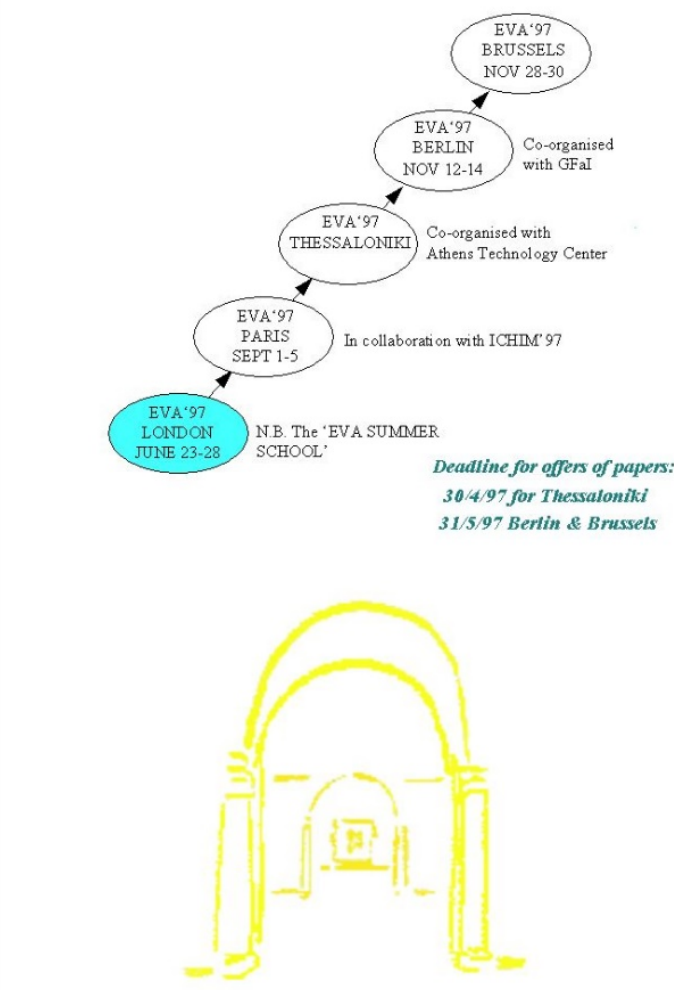

For information on the specific Events, use the menu above. The following is only General Information including:

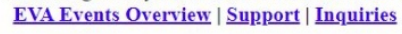

\section{Events Overview}

EVA '97: In this, the eighth annual London EVA Event we are making an innovation - an intensive 3 day Summer School building upon the Tutorials of previous years. It consists of three streams for:- (a) Non-Technical Users, (b) Technical Staff, (c) Management. The two Conference days will be followed by a special European Projects day focusing on the forthcoming EU Framework V R\&D; Programme, 1999 - 2003.

\section{A Forum for Users, Suppliers \& Researchers}

The aims of this event is to provide a forum for the user, supplier and scientific research communities to meet and exchange experiences, ideas and plans. Participants will receive up to date international news on new EC and International Arts Computing k Telecomms initiatives and projects in the visual arts field including archaeology and history.

Figure 7: The EVA web page in 1997 (https://web.archive.org/web/19970618054330/ http://brameur.co.uk/vasari/eva/).

A little later, in the year 2000, Jim Hemsley wrote to me in his characteristically friendly and generous style, concerning the planned EVA Scotland conference: 
Dear Jonathan,

I hope that you are well and thriving. I [...] am now focusing on the EVAs in 'semi-retirement'. You will see from the enclosed brochure that 'Cultural Web Portals' is a key topic at EVA 2000 Scotland. As their 'father' it would be great to see you there - as a 'VIP Guest' and/or how about a paper on this at EVA 2001 Scotland in

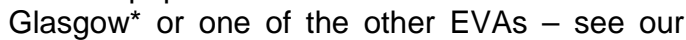
Web-site for news/calls.

Hoping to see you again soon.

Best wishes

Jim

* Deadline 30/11/2000

Although I was unable to take up his kind offer, having recently been appointed to a Chair at London South Bank University, it was not long before I became much more involved with EVA London. Jim was always a master in encouraging people to be involved with EVA and any other endeavour that he supported.

\section{EVA LONDON IN THE $21^{\text {ST }}$ CENTURY}

From 2003, I have been involved with the EVA London conference every year in some way, initially as a keynote speaker on web accessibility (Bowen 2003), in 2004 and 2005 as a co-presenter (Beler et al. 2004; Filippini-Fantoni \& Bowen 2005; Numerico \& Bowen 2005), and then as a co-chair and proceedings editor from 2006 onwards.

\subsection{The EVA London Proceedings}

It is interesting to note how the main EVA London co-chairs (not always the same as the proceedings co-editors until 2007) and the conference locations have changed over the years, as recorded on the front of EVA London proceedings since 2003:

- 2003: Suzanne Keene, Anthony Hamber, James Hemsley - The Institute of Archaeology, University College London (Hemsley et al. 2003).

- 2004: Suzanne Keene, Anthony Hamber, James Hemsley - The London Institute of Archaeology, University College London (Hemsley et al. 2004).

- 2005: Suzanne Keene, James Hemsley University College London (Hemsley et al. 2005).

- 2006: Suzanne Keene, Jonathan P. Bowen, Lindsay MacDonald, James Hemsley - The Institute of Archaeology, University College London (Hemsley et al. 2006).

- 2007: Jonathan P. Bowen, Suzanne Keene, Lindsay MacDonald - London College of
Communication, University of the Arts London (Bowen et al. 2007).

- 2008: Stuart Dunn, Suzanne Keene, George Mallen, Jonathan P. Bowen - BCS London (Bowen et al. 2008).

- 2009: Alan Seal, Suzanne Keene, Jonathan P. Bowen - BCS London (Seal et al. 2009).

- 2010: Alan Seal, Jonathan P. Bowen, Kia $\mathrm{Ng}$ - BCS London (Seal et al. 2010).

- 2011: Jonathan P. Bowen, Stuart Dunn, Kia $\mathrm{Ng}$ - BCS London (Bowen et al. 2011).

- 2012: Stuart Dunn, Jonathan P. Bowen, Kia $\mathrm{Ng}$ - BCS London (Dunn et al. 2012).

- 2013: Kia Ng, Jonathan P. Bowen, Sarah McDaid - BCS London ( $\mathrm{Ng}$ et al. 2013). See Figure 8 below.

- 2014: Kia Ng, Jonathan P. Bowen, Sarah McDaid - BCS London (Ng et al. 2014).

- 2015: Kia Ng, Jonathan P. Bowen, Nick Lambert - BCS London ( $\mathrm{Ng}$ et al. 2015).

- 2016: Jonathan P. Bowen, Graham Diprose, Nick Lambert - BCS London (Bowen et al. 2016).

- 2017: Jonathan P. Bowen, Graham Diprose, Nick Lambert - BCS London (Bowen et al. 2017).

- 2018: Jonathan P. Bowen, Jon Weinel, Graham Diprose, Nick Lambert - BCS London (Bowen et al. 2018).

- 2019: Jon Weinel, Jonathan P. Bowen, Graham Diprose, Nick Lambert - BCS London (Weinel et al. 2019).

- 2020: Jon Weinel, Jonathan P. Bowen, Graham Diprose, Nick Lambert - BCS London (Weinel et al. 2020).

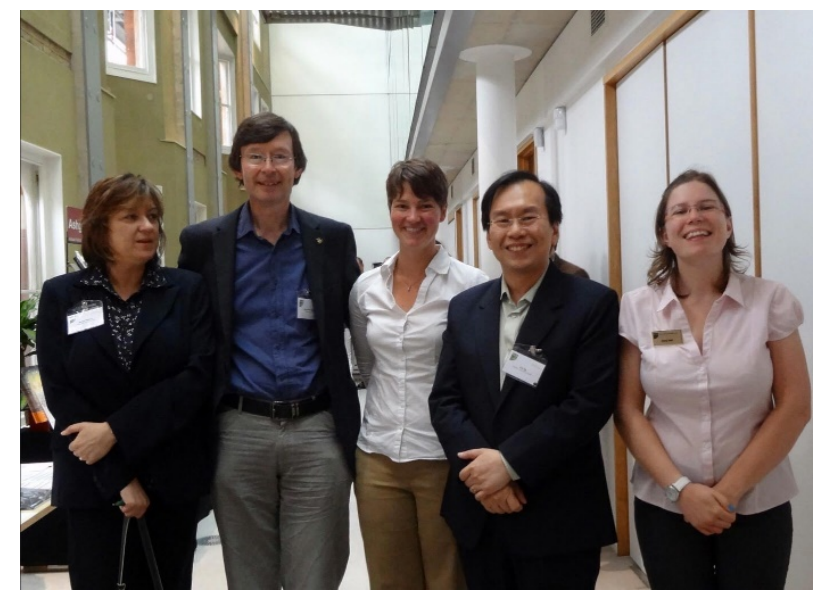

Figure 8: The co-editors Sarah McDaid, Jonathan Bowen, Kia Ng, and others, at EVA London 2013 in the BCS London office. (Courtesy of Kia Ng and Bee Ong.)

Table 1 shows the co-editor information for the EVA London proceedings during 2003-2020 visually, "•" Indicating the main (first) editor and "०" indicating other co-editors. It can be observed that most main editors are initially co-editors before they become the main editor and sometimes go back to 
helping as co-editor again after serving as the main editor. Editing the proceedings is a significant effort with much copyediting needed to maintain the quality of the EVA London proceedings. Guidance for editing papers has been produced by the author of this paper. Copyediting of papers takes at least a week in practice, potentially longer, but is a rewarding process, at least for a few years!

Table 1: EVA London co-editors, 2003-2020. Key: "•" main editor; "०" other co-editors.

\begin{tabular}{|c|c|c|c|c|c|c|c|c|c|c|c|c|c|}
\hline $\begin{array}{l}\frac{\mathscr{U}}{E} \\
\frac{\widetilde{\sigma}}{Z}\end{array}$ & 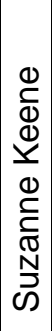 & 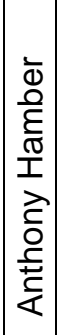 & 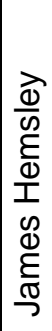 & 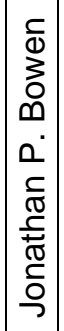 & 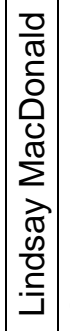 & 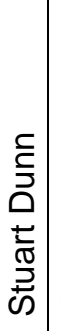 & $\begin{array}{l}\frac{\sigma}{d} \\
\overline{\bar{\sigma}} \\
\sum \\
\mathbb{d} \\
\overline{0} \\
d \\
0\end{array}$ & $\begin{array}{l} \\
\overline{\widetilde{\pi}} \\
\mathbb{\mathscr { N }} \\
\frac{\widetilde{\sigma}}{\mathbb{\alpha}}\end{array}$ & $\begin{array}{l} \\
\frac{2}{z} \\
\frac{\sigma}{x}\end{array}$ & 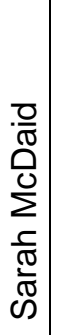 & 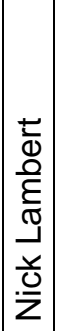 & 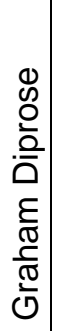 & 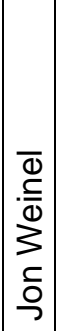 \\
\hline 2003 & $\bullet$ & 0 & 0 & & & & & & & & & & \\
\hline 2004 & $\bullet$ & 0 & 0 & & & & & & & & & & \\
\hline 2005 & $\bullet$ & & 0 & & & & & & & & & & \\
\hline 2006 & $\bullet$ & & & 0 & 0 & & & & & & & & \\
\hline 2007 & 0 & & & $\bullet$ & 0 & & & & & & & & \\
\hline 2008 & 0 & & & 0 & & • & 0 & & & & & & \\
\hline 2009 & 0 & & & 0 & & & & $\bullet$ & & & & & \\
\hline 2010 & & & & 0 & & & & $\bullet$ & 0 & & & & \\
\hline 2011 & & & & $\bullet$ & & 0 & & & 0 & & & & \\
\hline 2012 & & & & 0 & & $\bullet$ & & & 0 & & & & \\
\hline 2013 & & & & 0 & & & & & • & 0 & & & \\
\hline 2014 & & & & 0 & & & & & • & 0 & & & \\
\hline 2015 & & & & 0 & & & & & - & & 0 & & \\
\hline 2016 & & & & - & & & & & & & 0 & 0 & \\
\hline 2017 & & & & $\bullet$ & & & & & & & 0 & 0 & \\
\hline 2018 & & & & $\bullet$ & & & & & & & 0 & 0 & 0 \\
\hline 2019 & & & & 0 & & & & & & & 0 & 0 & $\bullet$ \\
\hline 2020 & & & & 0 & & & & & & & 0 & 0 & $\bullet$ \\
\hline
\end{tabular}

\subsection{Unexpected Consequences and Serendipity}

EVA London has spawned many interdisciplinary collaborations. For example, in my case after seeing Giannini (2013) presented at EVA London 2013, I visited the paper's author at the Pratt Institute in New York to teach a masters course concerning online museums, and this has led to many subsequent EVA London papers (Bowen \& Giannini 2014; Giannini \& Bowen 2015; 2016; 2017; 2018; 2019c; 2020). This in turn has led to the establishment of the EVA London Symposium from 2016 onwards (Bowen \& Giannini 2016; Bowen et al. 2017; 2018c; 2019; 2020), including sponsorship by the Pratt Institute. Further, these papers and the symposium have inspired a collaborative edited book on Museums and Digital
Culture (Giannini \& Bowen 2019a), including many EVA London presenters as chapter authors, launched at EVA London 2019.

\subsection{The EVA London Website}

The EVA London website has been maintained under http://www.eva-london.org in recent years. It now uses WordPress software at the suggestion of Tom Ensom, a previous EVA London organisation committee member, and this is certainly better for access through smartphones, which are used increasingly for web access nowadays. The change of website provision is always problematic with respect to maintaining previous web information, although some of this is still accessible from the Internet Archive (https://web.archive.org/web/*/ www.eva-london.org).

\subsection{EVA Conferences International}

Jim Hemsley was a master cajoler (in the nicest possible way) and organiser in terms of expanding the EVA "empire" from London to Europe and around the world. He set up EVA Conferences International as a non-profit umbrella organisation for EVA activities. Now that he is retired, the EVA London organising committee has attempted to replicate his energy in this regard, but it has been an uphill battle for others. Finding the right person with the motivation and personal skills has proved difficult. We hope that the current EVA International representative on the EVA London organising committee, Terry Trickett, will have the drive and time to take this forward, with coordination and perhaps funding (e.g., from the European Commission) for the various EVA conferences. We do have an EVA International mailing list on the UK academic JISCmail facility and look forward to developments in this regard.

\section{COMMUNITY OF PRACTICE}

A Community of Practice (CoP) is a social science concept for modelling the activities of professional communities with a common goal (Wenger-Trayner $\&$ Wenger-Trayner 2015). It can be used in various scenarios, for example, a museum user community (Liu and Bowen, 2011). A CoP consists of:

(i) A domain of knowledge and interest. In the case of EVA, this is electronic visualisation in the context of the arts, culture, and heritage, so very interdisciplinary.

(ii) A community around this domain. For EVA, this included the organising committee at the centre, the programme committee and presenters, conference delegates, and more generally, potential 
delegates with an interest in electronic visualisation.

(iii) The practice undertaken by the community in this domain, developing its knowledge. EVA is very interdisciplinary, with digital artists, technologists, and other related specialists such as museum curators, archaeologists, etc. The interaction at EVA conferences across disciplines is beneficial to all involved.

There are various stages in the development of a CoP (Wenger n.d.):

(i) Potential: There needs to be an existing network of people to initiate a CoP. In the case of EVA, the European VASARI project was the starting point.

(ii) Coalescing: The community needs to establish a rhythm to ensure its continuation. In EVA's case, an annual conference was established initially in London.

(iii) Maturing: The community must become more enduring. EVA London spawned further EVA conferences in Europe from the mid to late 1990s and then worldwide.

(iv) Stewardship: The community needs to respond to its environment and develop appropriately. EVA has interacted with related organizations such as the Lumen Prize, RCA, V\&A, Art in FLUX, etc., and has fostered these relationships as appropriate.

(v) Legacy: All communities end eventually, if successful morphing into further communities. EVA has not yet reached this stage, but ideally it should plan for it at the appropriate time.

It remains to be seen what legacy EVA leaves in the future. For the moment, EVA continues to be in a strong state of stewardship, adapting to new opportunities successfully as they present themselves, and there is no sign of EVA running out of steam yet.

\section{PRESENT TO FUTURE}

EVA London continues to thrive as a "boutique" conference. It has transformed itself into a conference with a digital art flavour, especially through its collaboration with the Art In FLUX group (http://www.artinfluxlondon.com) of London-based digital artists, led by artists Aphra Shemza, Maria
Almena, Oliver Gingrich, and others (Shemza et al. 2019).

Succession planning is always important for a group like the EVA London organisation committee. Obviously, people come and go in such a group (e.g., see Table 1 earlier), depending on their other commitments and circumstances. Jim Hemsley's tireless and very effective efforts in promoting EVA has meant that now he is officially retired (although still active), at least three committee members have been needed to replace him.

A committee for a conference like EVA (indeed, any successful Community of Practice) needs some key members ("champions") such as the current general chair (Graham Diprose), one of more programme chairs (currently the author and Jon Weinel), and the chair of the BCS Computer Arts Society (CAS, currently Nick Lambert), acting as EVA London's umbrella organisation. Other key roles include publicity (Sarah McDaid, former EVA London proceedings co-editor), international liaison (Terry Trickett), technical support, website maintenance, etc. For all these various roles, it is necessary to keep an eye out for potential new people to take on roles, typically from conference delegates that have attended and presented several times.

Symbiotic and synergistic relationships with other institutions and organisations is an important and ever-changing aspect of EVA London activities. Having the use of the BCS London offices effectively free through the BCS CAS connection is a significant bonus for keeping costs and registration fees to a reasonable level. As well as the BCS and CAS, EVA has had recent and/or ongoing relationships with the Lumen Prize (the leading international digital art award) (Papadimitriou et al. 2017), the Victoria \& Albert Museum, through Digital Futures exhibitions (Papadimitriou \& Bowen 2018), and the Royal College of Art for associated activities such as the Event Two exhibition (celebrating the $50^{\text {th }}$ anniversary of the Event One digital art exhibition originally held at the RCA in 1969).

The Pratt Institute in New York and RCA have sponsored the associated EVA London Symposium, a half to one-day event at the start of the conference. The FLUX group of digital artists has injected new blood into the organisation of EVA London - e.g., exhibiting at Event Two (Shemza et al. 2019) - and we are already planning an Event Three exhibition in 2069, at which some of the newer members of the EVA London family, especially FLUX artists, should be present!

New ideas for EVA London events keep the conference fresh and dynamic. As well as the 
associated Symposium, started in 2016 (Bowen \& Giannini 2016), Graham Diprose has initiated a Research Workshop for research students and digital artists, where a short paper can be presented in a friendly atmosphere with a bursary for the day. He has also started a "Research in Education" day at the end of the conference, where mainly London-based universities and colleges can bring a group of students for presentations and networking. Such new ideas are needed to keep EVA London relevant and innovative for the future.

\section{CONCLUSION}

The EVA London conference series has been highly successful over the last 30 years, spawning many EVA conferences around the world, some as one-off events, and others as a series of annual conferences. We anticipate a $60^{\text {th }}$ anniversary event in 2050 and all younger readers are invited to attend or even organise this!

\section{ACKNOWLEDGEMENTS}

Many thanks to Jim Hemsley for initiating the EVA London conferences in 1990, which has led to further EVA conferences around the world, and without which none of this would have been possible. Thank you to Jim for checking the factual correctness of the paper, especially during the early years of EVA. Thank you to Christina Hemsley for further comments. The European Commission has provided helpful project support related to EVA over the years. The author is grateful to all the EVA London co-chairs, organisation committee, programme committee, authors, and delegates, during his time working with the conference. $\mathrm{He}$ is also grateful to Museophile Limited for financial support.

\section{REFERENCES}

Beler, A., Borda, A., Bowen, J. P., and Filippini-Fantoni, S. (2004) The building of online communities: An approach for learning organizations, with a particular focus on the museum sector. In Hemsley et al. (2004), pp. 2.1-2.15. URL: https://arxiv.org/abs/cs/0409055 (retrieved 15 March 2020)

Bowen, J. P. (1995a) Exhibitions in the ether. The Times Higher Education Supplement, Multimedia features, $\mathrm{p}$. xii, 10 March.

Bowen, J. P. (1995b) The Virtual Library of museums. In G. Day (ed.), Proc. Museum Collections and the Information Superhighway, pp. 37-39. Science Museum, London, 10 May. URL: http://web.archive.org/web/ 19990120003322/www.nmsi.ac.uk/infosh/bowen.htm (retrieved 20 January 1999)

Bowen, J. P. (1995c) Collections of collections. Museums Journal, 95(8), pp. 24-25, August.
Bowen, J. P. (1995d) The World Wide Web Virtual Library of museums. Information Services \& Use, 15(4), pp. 317-324, October. DOI: 10.3233/ISU-1995-15408 Also in Hemsley (1995), pp. 105-114. 27 July.

Bowen, J. P. (1997) The Virtual Library museums pages (VLmp): Whence and whither? MW97: Museums and the Web 1997. URL: https://www.museumsandtheweb.com/ biblio/the virtual library museums pages vlmp whence and whi.html (retrieved 7 March 2020)

Bowen, J. P. (2003) Web access to cultural heritage for the disabled. In Hemsley et al. (2003), pp. s1:1-11. URL: https://arxiv.org/abs/cs/0307068 (retrieved 15 March 2020)

Bowen, J. P., Diprose, G., and Lambert, N. (eds.) (2016) EVA London 2016: Electronic Visualisation and the Arts. BCS, Electronic Workshops in Computing (eWiC). London, UK, 12-14 July. ISBN: 978-1-78017-344-3. ScienceOpen. DOI: 10.14236/ewic/eva2016.0

Bowen, J. P., Diprose, G., and Lambert, N. (eds.) (2017) EVA London 2017: Electronic Visualisation and the Arts. BCS, Electronic Workshops in Computing (eWiC). London, UK, 10-13 July. ISBN: 978-1-78017-399-3. ScienceOpen. DOI: $10.14236 /$ ewic/eva2017.0

Bowen, J. P., Dunn, S., and Ng, K. (eds.) (2011) EVA London 2011: Electronic Visualisation and the Arts. BCS, Electronic Workshops in Computing (eWiC). London, UK, 6-8 July. ISBN 978-1-906124-88-5

Bowen, J. P. and Giannini, T. (2014) Digitalism: The new realism? In $\mathrm{Ng}$ et al. (2014), pp. 324-331. DOI: 10.14236/ewic/eva2014.38

Bowen, J. P. and Giannini, T. (2016) From analogue to digital in literature and art. In Bowen et al. (2016), pp. 14. DOI: 10.14236/ewic/EVA2016.1

Bowen, J. P., Giannini, T., Ara, R., Lomas, A., and Siefring, J. (2019) States of Begin: Art and identity in digital space and time. In Weinel et al. (2019), pp. 1-9. DOI: 10.14236/ewic/EVA2019.1

Bowen, J. P., Giannini, T., and Polmeer, G. (2017) Coded communication: Digital senses and aesthetics, merging art and life. In Bowen et al. (2017), pp. 1-8. DOI: 10.14236/ewic/EVA2017.1

Bowen, J. P., Giannini, T., Polmeer, G., Falconer, R., Miller, A. I., and Dunn, S. (2020) Computational Culture and $\mathrm{Al}$ : Challenging human identity and curatorial practice. In Weinel et al. (2020), this volume.

Bowen, J. P., Giannini, T., Polmeer, G., Gannis, C., Gardiner, J., Kearney, J., Wands, B., and Weinel, J. (2018a) States of Begin: Art and identity in digital space and time. In Bowen et al. (2018c), pp. 1-7. DOI: 10.14236/ewic/EVA2018.1

Bowen, J. P., Keene, S., and MacDonald, L. (eds.) (2007) EVA London 2007 Conference Proceedings, London College of Communication, University of the Arts London, UK, 11-13 July. ISBN: 0-9543146-8-9

Bowen J. P., Keene, S., and Ng, K. (eds.) (2013) Electronic Visualisation in Arts and Culture. Springer, Series on Cultural Computing. DOI: 10.1007/978-1-4471$\underline{5406-8}$

Bowen, J. P., Weinel, J., Diprose, G., and Lambert, N. (eds.) (2018) EVA London 2018: Electronic Visualisation and the Arts. BCS, Electronic Workshops in Computing (eWiC). London, UK, 9-13 July. ISBN: 978-1-78017-4549. ScienceOpen. DOI: $\underline{10.14236 / \text { ewic/eva2018.0 }}$ 
Dunn, S., Bowen, J. P., and Ng, K. (eds.) (2012) EVA London 2012: Electronic Visualisation and the Arts. BCS, Electronic Workshops in Computing (eWiC). London, UK, 10-12 July. ISBN: 978-1-78017-159-3. ScienceOpen. DOI: $\underline{10.14236 / \text { ewic/eva2012.0 }}$

Dunn, S., Keene, S., Mallen, G., and Bowen, J. P. (eds.) (2008) EVA London 2008: Conference Proceedings. BCS, London, UK, 22-24 July. ISBN 978-1-906124-07-6

Filippini-Fantoni, S. and Bowen, J. P. (2005) Can small museums develop compelling, educational and accessible web resources? The case of Accademia Carrara. In Hemsley et al. (2005), pp. 18.1-18.14. URL: https://arxiv.org/abs/cs/0508066 (retrieved 15 March 2020)

Gaia, G., Boiano, S. Bowen, J. P., and Borda, A. (2020) Museum websites of the first wave: The rise of the virtual museum. In Weinel et al. (2020), this volume.

Giannini, T. (2013) Visualizing Brooklyn: The Brooklyn Visual Heritage website. In $\mathrm{Ng}$ et al. (2013), pp. 9-16. DOI: $10.14236 /$ ewic/eva2013.2

Giannini, T. and Bowen, J. P. (2015) Galois connections: Mathematics, art, and archives. In Ng et al. (2015), pp. 176-191. DOI: 10.14236/ewic/EVA2015.18

Giannini, T. and Bowen, J. P. (2016) Curating digital life and culture: Art and information. In Bowen et al. (2016), pp. 237-244. DOI: 10.14236/ewic/EVA2016.46

Giannini, T. and Bowen, J. P. (2017) Life in code and digits: When Shannon met Turing. In Bowen et al. (2017), pp. 51-58. DOI: 10.14236/ewic/EVA2017.9

Giannini, T. and Bowen, J. P. (2018) Of museums and digital culture: A landscape view. In Bowen et al. (2018), pp. 172-179. DOI: 10.14236/ewic/EVA2018.34

Giannini, T. and Bowen, J. P. (eds.) (2019a) Museums and Digital Culture: New perspectives and research. Springer, Series on Cultural Computing. DOI: 10.1007/978-3-319-97457-6

Giannini, T. and Bowen, J. P. (2019c) Art and Activism at museums in a post-digital world. In Weinel et al. (2019), pp. 27-35. DOI: 10.14236/ewic/EVA2019.4

Giannini, T. and Bowen, J. P. (2020) Computing the Future: Digital encounters in art and science when da Vinci meets Turing. In Weinel et al. (2020), this volume.

Hemsley, J. (ed.) (1995) EVA'95: Electronic Imaging \& the Visual Arts Conference Proceedings. Sainsbury Wing, National Gallery, London, UK, 27 July. ISBN: 09519980-7-2.

https://www.worldcat.org/search?q=isbn\%3A

9780951998076 (15 March 2020)

Hemsley, J. (2013) The EVA London Conference 19902012: Personal reflections. In Bowen et al. (2013), pp. 15. DOI: $10.1007 / 978-1-4471-5406-81$

Hemsley, J., Cappellini, V., and Stanke G. (eds.) (2003) EVA 2003 London Conference Proceedings, University College London, UK, 22-26 July. ISBN: 0-9-543146-3-8

Hemsley, J., Cappellini, V., and Stanke G. (eds.) (2004) EVA 2004 London Conference Proceedings, University College London, UK, 26-31 July. ISBN: 0-9543146-4-6

Hemsley, J., Cappellini, V., and Stanke G. (eds.) (2005) EVA 2005 London Conference Proceedings, University College London, UK, 25-29 July. ISBN: 0-9543146-6-2
Hemsley, J., Keene, S., MacDonald, L., Bowen, J. P., Cappellini, V., and Stanke G. (eds.) (2006) EVA 2006 London Conference Proceedings, University College London, UK, 26-28 July. ISBN: 0-9543146-7-0

Liu, A. and Bowen, J. P. (2011) Creating online collaborative environments for museums: A case study of a museum wiki. International Journal of Web Based Communities, 7(4), pp. 407-428. DOI: 10.1504/ IJWBC. 2011.042988

Ng, K., Bowen, J.P., and Lambert, N. (eds.) (2015) EVA London 2015: Electronic Visualisation and the Arts. BCS, Electronic Workshops in Computing (eWiC). London, UK, 7-9 July. ISBN: 978-1-78017-316-0. ScienceOpen. DOI: 10.14236/ewic/eva2015.0

Ng, K., Bowen, J.P., and McDaid, S. (eds.) (2013) EVA London 2013: Electronic Visualisation and the Arts. BCS, Electronic Workshops in Computing (eWiC). London, UK, 29-31 July. ISBN: 978-1-78017-215-6. ScienceOpen. DOI: $10.14236 /$ ewic/eva2013.0

Ng, K., Bowen, J.P., and McDaid, S. (eds.) (2014) EVA London 2014: Electronic Visualisation and the Arts. BCS, Electronic Workshops in Computing (eWiC). London, UK, 8-10 July. ISBN: 978-1-78017-285-9. ScienceOpen. DOI: $10.14236 /$ ewic/eva2014.0

Numerico, T. and Bowen, J. P. (2005) Copyright and promotion: Oxymoron or opportunity. In Hemsley et al. (2005), pp. 25.1-25.10. URL: https://arxiv.org/abs/cs/ 0508067 (retrieved 15 March 2020)

Papadimitriou, I., Addis, J., Lomas, A., Dekker, L., Singporewala, K., and Tresset, P. (2017) Digital Futures: Lumen Big Reveal. In Bowen et al. (2017), pp. 438-440. DOI: 10.14236/ewic/eva2017.86

Papadimitriou, I. and Bowen, J. P. (2018) Digital Futures: Exhibits at EVA London 2018. In Bowen et al. (2018), pp. 41-42. DOI: 10.14236/ewic/eva2018.8

Seal, A., Keene, S., and Bowen, J. P. (eds.) (2009) EVA London 2009: Electronic Visualisation and the Arts. BCS, London, UK, 6-8 July. ISBN 978-1-906124-17-5

Seal, A., Keene, S., and Bowen, J. P. (eds.) (2010) EVA London 2010: Electronic Visualisation and the Arts. BCS, Electronic Workshops in Computing (eWiC). London, UK, 5-7 July. ISBN 978-1-906124-65-6

Shemza, A., Almena, M., Gingrich, O. (2019) Art in Flux at Event Two. In Weinel et al. (2019), pp. 172-173. DOI: 10.14236/ewic/EVA2019.33

Weinel, J., Bowen, J. P., Diprose, G., and Lambert, N. (eds.) (2019) EVA London 2019: Electronic Visualisation and the Arts. BCS, Electronic Workshops in Computing (eWiC). London, UK, 8-12 July. ISBN: 978-1-78017-5225. ScienceOpen. DOI: 10.14236/ewic/EVA2019.0

Weinel, J., Bowen, J. P., Diprose, G., and Lambert, N. (eds.) (2020) EVA London 2020: Electronic Visualisation and the Arts. BCS, Electronic Workshops in Computing (eWiC). London, UK, 6-10 July. ISBN: 978-1-78017-5386. ScienceOpen. DOI: 10.14236/ewic/EVA2020.0

Wenger, E. (n.d.) Communities of practice: Development stages. URL: http://esflive.archiv.zsi.at/files/CoP development stages.pdf (retrieved 9 March 2019)

Wenger-Trayner, E. and Wenger-Trayner, B. (2015) Introduction to communities of practice: A brief overview of the concept and its uses. URL: https://wengertrayner.com/introduction-to-communities-of-practice/ (retrieved 9 March 2019) 